\title{
Expression of Bacillus thuringiensis Toxin Affects the Leaf Anatomy of a Cotton Hybrid
}

\author{
V. T. Sundaramurthy
}

The Crops Foundation Trust, Veerakeralam, Coimbatore, Tamil nadu (641 007), India

\section{Article History}

Manuscript No. AR732b

Received in $26^{\text {th }}$ April, 2014

Received in revised form $15^{\text {th }}$ October, 2014

Accepted in final form $18^{\text {th }}$ January, 2015

\section{Correspondence to}

${ }^{*} E$-mail: vt.smurthy@yahoo.in

\section{Keywords}

Cotton, hybrid, Bt-alien gene, leaf, anatomy, stomata

\begin{abstract}
The transgenic cotton hybrids that carry an alien gene cry1Ac construct from Bacillus thuringiensis Berliner variety kurstaki is known to confer resistance to bollworm of cotton. But no information is known to science on the effects of the toxin produced by the alien gene on the anatomy of the leaf of transgenic cotton hybrid.Hence the light microscopic method was employed to investigate the effect of the alien gene on the leaf anatomy of a cotton hybrid. The alien gene crylAc toxin had altered the size of the various tissue components of the leaf of the transgenic cotton hybrid. The different cells of the leaf of the Bt-cotton hybrid had under gone varying degrees of reduction in size as compared to its conventional isogenic cotton hybrid. The accessory vascular bundle was present around the main vascular strands in the transgenic cotton hybrid with more number of xylem vessels. While it was absent in the conventional cotton hybrid. The density of stomata was two fold higher with increased sizes of guard cells and stoma on the adaxial surface of the leaf in the transgenic cotton hybrid as compared to the conventional cotton hybrid. These changes are considered as an adoptive mechanism to enhance the uptake of water and nutrients from the soils for enhanced synthesis of photosynthate to support its growth, yield of seed cotton and development of fibre.
\end{abstract}

\section{Introduction}

Cotton is an important commercial crop which contributes significantly to the world economy and civilization of humanity by providing the fibre, food and other industrial raw materials. The cultivation of this crop has become non-profitable in several production centers due to insect pests which are responsible for $40-60 \%$ loss of yield (Sundaramurthy, 2002) and escalated dependency on the chemical insecticides for managing them. Increased dependency on the insecticides have resulted in serious ecological problems such as the contamination of food chain with the pesticides, environmental pollution, health hazards to the living beings (Robert van den Boch, 1980) development of insect resistance to insecticides (Brown, 1968) and resurgence of non-target pests (Sundaramurthy, 1994). The polygene controlled plant secondary chemicals which offer resistance to insects and the efforts made over several decades to transfer the polygenic traits into cotton cultivars through the conventional method of breeding for imparting resistant to insect pests has not yielded desired results. The gene (Hofte et al., 1986, Fischoff et al., 1987) that expresses certain toxin (Perlak et al., 1990) transferred into the cotton plant from a bacterium Bacillus thuringiensis Berliner variety kurstaki for effective management of insect-pests. The transgenic Bt -cotton is considered as a an alternative for subsistence of the production and productivity of cotton under the current exiquency and making inroads in several countries as it reduces the dependency on insecticides (James, 2003, Dong et al., 2004). As information on the internal anatomy of the leaf of cotton in the presence of toxin expressed by the alien gene is not known, the present study was carried out with the cotton hybrid and the results of the investigation are presented in this paper.

\section{Materials and Methods}

The commercial $\mathrm{Bt}$ and conventional isogenic cotton hybrids were developed from the same genome of Gossyipium hirsutum, L. and raised under irrigation during the winter season on the red loamy soil by giving a planting distance of 90 $\mathrm{cm}$ between rows and $60 \mathrm{~cm}$ between plants. Same agronomical practices were given for both the hybrids including the split application of fertilizers, Nitrogen: $\mathrm{P}_{2} \mathrm{O}_{5:} \mathrm{K}_{2} \mathrm{O}$ at 120-60-60 $\mathrm{kg} \mathrm{ha}^{-1}$. The yield of the seed cotton from each plant were recorded. The seed cotton was ginned by using electrically 
operated laboratory Gin. The ginned cotton was pooled into three samples and subjected to quality analyses by following the standard methods.

For anatomical study of the leaf the third fully expanded leaves from the terminal of main stem of the hybrids were removed from randomly selected plants on $70^{\text {th }}$ day after germination, dissected and fixed in FAA for anatomical studies by employing light microscopy. The fixed materials were processed and embedded in paraffin wax of MP at $60^{\circ} \mathrm{C}$ (Sass, 1940). The materials were sectioned to $10-12 \mu \mathrm{m}$ thickness (Johansen, 1940), dewaxed and stained with Toludin blue (O'Brien et al., 1964).

The stomatal profile of the leaf was studied on the fully grown up leaf from the three plants selected at random. The Nail polish fluid was spread as a thin film over both the surfaces of the selected leaves to prepare the external structure of stomata. The film on drying was peeled off and mounted on the slides.The number and sizes of the stomata were recorded respectively by using Meopta and Carl Zeiss light microscopes. All measurements were made randomly at five places on each slide from each leaf. The mean data were used to work out the standard error of differences (SEd) by employing the ExcelTool Package. The method of Sass (1940) was also employed for studying the stomatal morphology. Photomicrographs were prepared with Nikon Lab Hot 2 Microscopic Unit. The anatomical features as described by Easu (1964) were adopted in the present study.

\section{Results and Discussion}

The results of the effects of Bt- toxin expressed by the cry $1 \mathrm{Ac}$ alien gene on the anatomical changes in the leaf of the cotton hybrid and on the productivity of the cotton hybrid are presented in this paper. The number of bolls and productivity of Bt-cotton hybrid were better than the conventional cotton hybrid by recording $184.0 \mathrm{~g} \mathrm{plant}^{-1}$ as against $95.6 \mathrm{~g} \mathrm{plant}^{-1}$ by the conventional hybrid. But there were no significant differences in the ginning out turn, seed and lint indices, mean length, micronaire and strength of the fibre in Bt-cotton hybrid over the conventional isogenic cotton hybrid.

The results of histology of the leaves of hybrids revealed that there were no changes in the basic structure of the cells and their arrangements in the leaf of both $\mathrm{Bt}$ and conventional cotton hybrids. However, there was a considerable reduction in sizes of various tissue components of the leaf of the Btcotton hybrid than that of the conventional one (Table 1). The laminar thickness and upper epidermal zone in Bt-cotton hybrid were reduced by 18.49 and $5.88 \%$ respectively as against the conventional cotton hybrid. Indeed the lower epidermal and palisade zones remained same in both the hybrids. The size of the spongy mesophyll zone where in the cells are scattered
Table 1: The economic traits and variations in the anatomy of the leaf of the cotton hybrids. Mean value with \pm standard error of difference (The values in the parentheses are per cent decrease (-) or increase $(+)$ over the conventional hybrid)

\begin{tabular}{|c|c|c|}
\hline & $\begin{array}{l}\text { Conventional } \\
\text { Cotton Hybrid }\end{array}$ & Bt-Cotton Hybrid \\
\hline A. Economic traits & & \\
\hline $\begin{array}{l}\text { Seed cotton yield } g \\
\text { plant }^{-1}\end{array}$ & $95.60 \pm 7.02$ & $\begin{array}{c}184.00 \pm 20.31 \\
(+92.46)\end{array}$ \\
\hline Ginning percent & $36 \pm 0.71$ & $35 \pm 0.55(-2.86)$ \\
\hline Lint index & $6.5 \pm 0.12$ & $6.5 \pm 0.12(0.0)$ \\
\hline $\begin{array}{l}\text { Seed index } \\
\text { B. Quality of fibre: }\end{array}$ & $11.5 \pm 0.03$ & $11.8 \pm 0.21(-2.54)$ \\
\hline Mean length mm @,2.5\% & $29.8 \pm 0.06$ & $30.2 \pm 0.06(+1.34)$ \\
\hline Micronaire & $3.6 \pm 0.06$ & $3.6 \pm 0.0(0.0)$ \\
\hline $\begin{array}{l}\text { Strengthg tex } \\
\text { C. Histology of leaf }\end{array}$ & $22.4 \pm 0.11$ & $21.8 \pm 0.06(-1.83)$ \\
\hline I. Lamina & & \\
\hline Thickness $(\mu \mathrm{m})$ & $292.00 \pm 34.9$ & $\begin{array}{c}238.00 \pm 41.47 \\
(-18.49\end{array}$ \\
\hline Upper epidermis $(\mu \mathrm{m})$ & $34.00 \pm 5.48$ & $\begin{array}{c}32.00 \pm 4.47 \\
(-5.88)\end{array}$ \\
\hline Lower epidermis $(\mu \mathrm{m})$ & $20.00 \pm 0.0$ & $20.00 \pm 0.0(0)$ \\
\hline Palisade cells $(\mu \mathrm{m})$ & $158.00 \pm 21.68$ & $\begin{array}{c}122.00 \pm 16.43 \\
(-22.78)\end{array}$ \\
\hline $\begin{array}{l}\text { Spongy mesophyll zone: } \\
\text { Number of layers }\end{array}$ & $4.60 \pm 0.55$ & $4.20 \pm 0.84(-4.35)$ \\
\hline $\begin{array}{l}\text { Lateral veins } \\
\text { II. Mid rib }\end{array}$ & Prominent & Not prominent \\
\hline Height (mm) & $1.86 \pm 1.19$ & $\begin{array}{c}1.18 \pm 1.23 \\
(-36.56)\end{array}$ \\
\hline \multicolumn{3}{|l|}{ Adaxial hump } \\
\hline Height $(\mu \mathrm{m})$ & $774.00 \pm 61.89$ & $\begin{array}{c}344 \pm 32.09 \\
(-55.56)\end{array}$ \\
\hline Width $(\mu \mathrm{m})$ & $630.00 \pm 130.38$ & $\begin{array}{c}460 \pm 38.08 \\
(-26.98)\end{array}$ \\
\hline \multicolumn{3}{|l|}{ Abaxial region } \\
\hline Height $(\mu \mathrm{m})$ & $512.00 \pm 85.00$ & $\begin{array}{c}356 \pm 28.81 \\
(-30.47)\end{array}$ \\
\hline $\begin{array}{l}\text { Width }(\mathrm{mm}) \\
\text { Vascular strand }\end{array}$ & $1.63 \pm 0.22$ & $1.0 \pm 0.28(-39.17)$ \\
\hline Height (mm) & $1.22 \pm 0.89$ & $\begin{array}{l}0.508 .0 \pm 0.84 \\
(-56.46)\end{array}$ \\
\hline Width $(\mu \mathrm{m})$ & $660.00 \pm 60.55$ & $\begin{array}{c}531.8 \pm 52.69 \\
(-23.03)\end{array}$ \\
\hline $\begin{array}{l}\text { Number of xylem } \\
\text { element: }\end{array}$ & $7.6 \pm 0.55$ & $\begin{array}{c}10.0 \pm 1.22 \\
(+24.00)\end{array}$ \\
\hline $\begin{array}{l}\text { Dimension of xylem } \\
(\mu \mathrm{m}) \\
\text { Phloem zone }\end{array}$ & $50 \pm 0.00$ & $50 \pm 0.00(0)$ \\
\hline Width $(\mu \mathrm{m})$ & $794 \pm 32.86$ & $\begin{array}{c}350 \pm 10.00 \\
(-55.92)\end{array}$ \\
\hline
\end{tabular}

to continue..... 


\begin{tabular}{lcc}
\hline $\begin{array}{l}\text { III. Accessory vascular } \\
\text { bundles }\end{array}$ & Absent & Two in number \\
$\begin{array}{l}\text { IV. No. of stomata } \\
\text { Adaxial surface }\end{array}$ & $11.1 \pm 3.73$ & $22.0 \pm 7.21(+10.0)$ \\
Abaxial surface & $20.1 \pm 7.30$ & $20.0 \pm 6.68(0)$ \\
V. Guard cells & & \\
Adaxial surface & & \\
Length $(\mu \mathrm{m})$ & $22.20 \pm 2.82$ & $28.91 \pm 2.07(+25.36)$ \\
Width $(\mu \mathrm{m})$ & $14.82 \pm 2.19$ & $19.0 \pm 2.25(+27.38)$ \\
Stoma $(\mu \mathrm{m})$ & $3.50 \pm 1.25$ & $6.6 \pm 1.22(+88.57)$ \\
Abaxial surface & & \\
Length $(\mu \mathrm{m})$ & $30.72 \pm 2.38$ & $29.4 \pm 1.66(-4.29)$ \\
Width $(\mu \mathrm{m})$ & $19.70 \pm 0.83$ & $22.5 \pm 3.71(+14.21)$ \\
Stoma $(\mu \mathrm{m})$ & $4.80 \pm 1.60$ & $6.9 \pm 1.09(+43.75)$ \\
\hline
\end{tabular}

one above the other with in its sphere of their presence down from the palisade cells to upper limit of lower epidermis had also suffered a reduction of $22.78 \%$ and they appeared to have arranged arbitrarily in four layers in Bt-cotton hybrid in contrast to their arrangements as five arbitrary layers in the conventional hybrid. The lateral vein and bundle sheath were less prominent in the Bt-cotton hybrid as against the conventional hybrid which had a prominent lateral vein and a thick bundle sheath. The adaxial hump and abaxial regions of the leaf mid rib in Bt-cotton hybrid were greatly reduced by $55.56 \%$ in contrast to the conventional cotton hybrid. The adaxial median bundles and the bundle sheath extension were totally absent in Bt-cotton hybrid. The vertical and horizontal planes of the vascular strand in Bt-cotton had suffered a reduction of 56.46 and $23.03 \%$ respectively with increased number of xylem elements by $24 \%$ as compared to conventional hybrid. There were no changes either in the presence of crystals or in the dimensions of the xylem elements in both hybrids. It is evident that there was reduction of phloem zone in Bt-Cotton hybrid by $55.92 \%$ as compared to that of the conventional one. A striking feature observed in the modified hybrid was the presence of two inverted collateral adaxial accessory bundles which were positioned over its main vascular strand and this feature was found to be absent in the conventional cotton hybrid (Figure $1 \& 2)$.

There was a difference in the density of stomata between Bt and conventional hybrids (Figure 3a,b\&c). The number of stomata presents on the adaxial surface of the leaf of Bt-cotton hybrid was 22 as against 11.1 cells field at $45 \times 10$ magnification in the conventional cotton hybrid. The abaxial surface of the leaf of both the hybrids had same numbers of stomata. The sizes of the guard cells in the stomata also differed in both the hybrids. The guard cells those were present on the adaxial surface of the leaf of the Bt-cotton hybrid were $28.91 \mu \mathrm{m}$ long and 19.00 $\mu \mathrm{m}$ wide as against $22.20 \mu \mathrm{m}$ long and $14.82 \mu \mathrm{m}$ wide in the conventional cotton hybrid while they were measuring 29.4 $\mu \mathrm{m}$ long and $22.48 \mu \mathrm{m}$ wide in Bt-cotton hybrid and 30.72 $\mu \mathrm{m}$ long and $19.70 \mu \mathrm{m}$ wide in the conventional cotton hybrid on the abaxial surface of the leaf. However the stoma was comparatively wider by 43 to $88 \%$ respectively on adaxial surface and abaxial surface of the leaf of Bt-cotton hybrid as compared to that of the conventional cotton hybrid.

The presence of toxin in the leaf (Kranthi et al., 2005) might have caused the observed changes as an adoptive mechanism as induced by UV-B radiation (Kakani et al., 2003). These changes might also be brought in by the possible interaction of alien genes with the native ones as genes control the organogenesis in the biological system (Scott, 2000). Interaction of alien genes with syntheses of plant hormones might be another cause for these changes as the growth and patterning of organs require specific hormones to accumulate in specific regions. The increased density of stomata in the leaves of Bt-cotton hybrid with increased sizes of guard cells with wider stoma might have resulted in increased transpiration rate as reported earlier in transgenic apples with MdPG1gene which had changed the composition of cell walls containing less pectin with malformed stomata and remained open during night to cause higher transpiration resulting in utilization of more water than the normal trees (Atkinson et al., 2002). The observed changes in the stomata and presence of accessory vascular bundles in the modified cotton hybrid might have taken more water from soil for photosynthetic activities than by the conventional cotton hybrid. Further increased number of xylem vessels in Bt-cotton hybrid might have also resulted in the translocation of more dissolved nutrients to the mesophyll tissue to enhance the stomatal conductance (Wise et al., 2000) for increasing the synthesis of photosynthate suggesting that such hybrids also would uptake more nutrients from the soils necessitates use of more fertilizers than in the conventional hybrid. The presences of accessory vascular bundles in the modified cotton hybrid support such hypotheses. Such hybrids should be cultivated in niches having assured irrigation all through the crop season with more fertilizer input for maximizing the yield and these may cause hydrological imbalances in the given system and escalate the cost of cultivation besides causing eutrophication phenomenon due to run-off of excessive nutrients from the cultivated niches to the adjoining ecosystem. The increased photosynthesis might have modified the nitrogen metabolism and increased the free amino acid, soluble protein, nitrate reductase and the glutamic-pyruvic transaminase activity as reported earlier (Radin et al., 1994, Chen et al., 2004, Dong et al., 2006, Lu et al., 1997) and such changes might be responsible not only for the observed higher yield in Btcotton hybrid over the conventional one but also for causing the ecological succession of other insect pests in the niche (Sundaramurthy, 2010). 

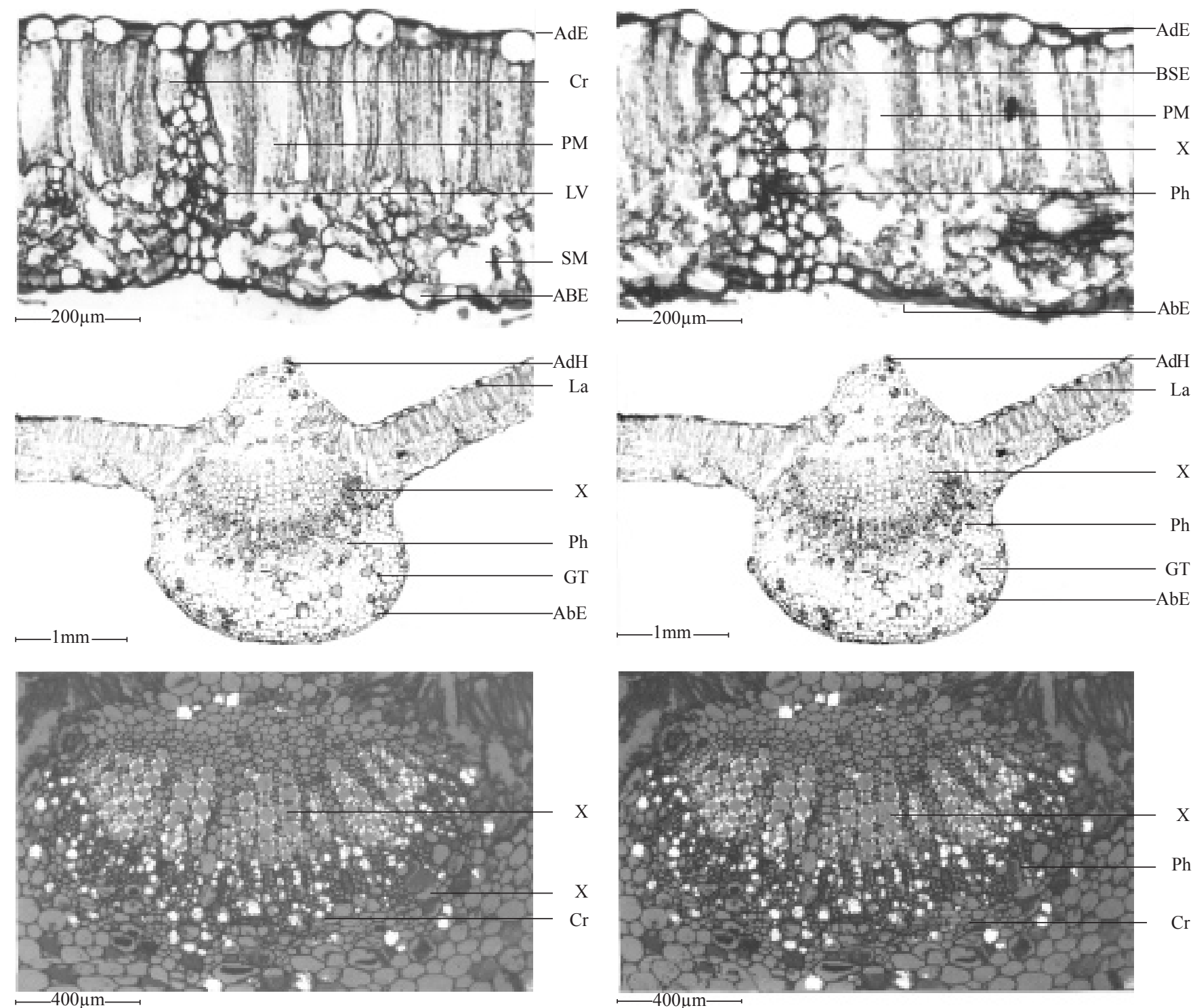

Figure 1: Transverse sections showing the internal anatomy of the A) lamina (10×5); B) midrib ( $4 \times 2.5)$; C) vascular strand and crystals as seen under Polaroid light microscopy $(10 \times 2.50)$ in the leaf of the conventional cotton hybrid

Figure 2: Transverse sections showing the internal anatomy of the A) lamina, B) Midrib $(4 \times 2.5)$, C) vascular strand and crystals as seen under Polaroid light Microscopy $(10 \times 2.5)$ in the leaf of the Bt-cotton hybrid in the leaf of Bt-cotton hybrid

LegendsforFigures 1\&2:Theanatomical features of the leafthatareshowninthefigures 1 and 2areEp-Epidermis,AdE-Adaxialepidermis, PM-Palisade mesophyll, SM: Spongy mesophyll; LA-Lamina,GT-Ground tissue, AdH-Adaxial hump, AdB-Adaxial bundle, MB-Median bundle, BSE-Bundle sheath extension, AbE-Abaxial Epidermis, AbM-Abaxial midrib, LV-Lateral vein, Ph-Phloem, X-Xylem,Cr-Crystal.

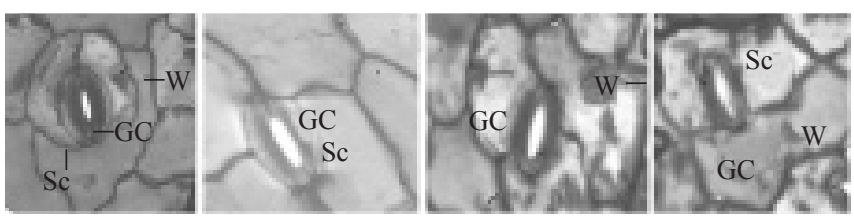

Figure 3a: Showing a single stoma on the leaf of the conventional cotton hybrid at its adaxial (a) and on the abaxial (b) and on the leaf of the Bt-cotton hybrid at its adaxial (c) and abaxial (d) surfaces with the guard cells (GC), subsidiary cells (SC), and anticlinal wall (W) $(40 \times 2.5)$

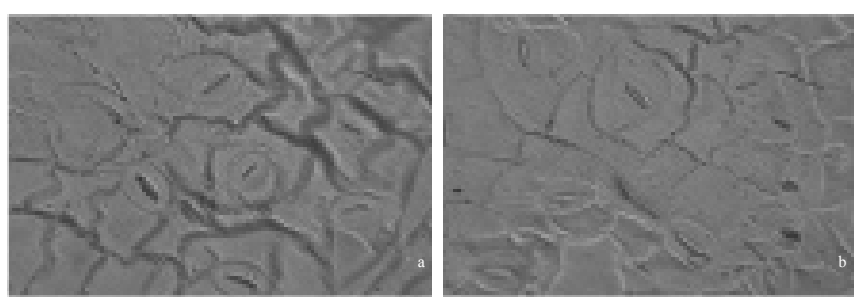

Figure $3 b$ : The imprint of stomata of the conventional cotton hybrid on its adaxial (a) and on the abaxial surfaces (b) $(40 \times 10)$ made on the film of nail polish 

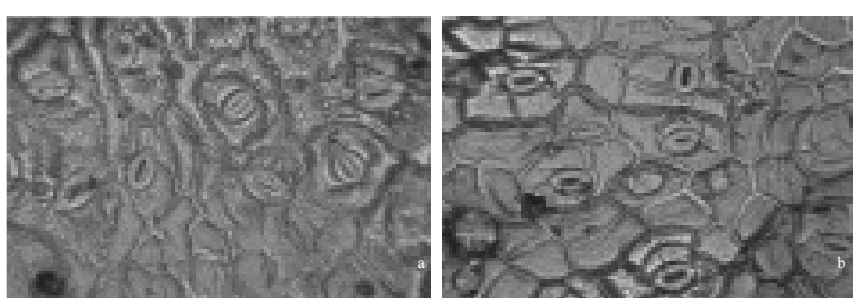

Figure 3c: The imprint of stomata of the Bt-cotton hybrid on its adaxial (a) and abaxial (b) surfaces $(40 \times 10)$

\section{Conclusion}

The results of the present study and enhanced metabolism of nitrogen reported earlier in the transgenic cotton may pave the way for exploring further into the cell biology and molecular mechanism under different situations with different genomes of cotton and alien gene constructs. These will lead to complete understanding on the exact mode of action of transgenes in the plant system. Interaction of these genes with native ones may possibly results in syntheses of newer metabolites in the plant system which may be secreted out through both the leaf and root as exudates. These newer metabolites may have great economic and environmental significance in future in the management of insect pests.

\section{Acknowledgement}

The helps rendered by Dr. S.E.S.A. Khader, Mr. P. Muthusamy, Central Institute for Cotton Research, Regional Station, Coimbatore, Tamilnadu and Dr.P.N.Gruraja Rao, Sugarcane Breeding Institute, Coimbatore, Tamilnadu for permitting to use the laboratory facilities are acknowkedged with thanks. Thanks are due to Dr. T.Ramanujam, Physiologist for going through the manuscript and to Mr. D.Suriya Narayanan for the photography.

\section{Reference}

Atkinson, R.G., Schroder, R., Hallett, I., Cohen, D., Macrae, E.A., 2002. Over expression of polygalacturonase in transgenic apple trees leads to a range of novel phenotypes involving changes in cell adhesion. Plant Physiology 129, 122-133.

Brown, A.W.A., 1968. Insecticide resistance comes of age. Bulletin of the Entomological Society of America 14, 3-9.

Chen, D.H., Ye, G.Y., Yang, C.Q., Chen, Y., Wu, Y.K., 2004. Effect after introducing Bacillus thuringiensis gene on nitrogen metabolism in cotton. Field Crops Research 87, 235-244.

Dong, H.Z., Li, W.J., Tang, W., Zhang, D.M., 2004. Development of hybrid Bt-cotton in China - a successful integration of transgenic technology and conventional techniques. Current Science 86, 778-782.

Dong, H.Z., Li, W. J., Tang ,W., Li, Z.H., Zhang, D.M., 2006.
Effects of genotypes and plant density on yield, yield components and photosynthesis in Bt transgenic cotton. Journal of Agronomy Crop Science 192, 132-139.

Esau, K., 1964. Plant Anatomy, John Wiley\&Sons. New York.

Fischoff, D.A., Bowdisch, K.S., Perlak, F.J., Marrone, P.G., Mccormic, S.H., Niedermeyer, J.G., Dean, D.A., KusanoKretzmer, K., Mayer, E. J., Rochester, D.E., Rogers, S.G., Fraley,. R.T., 1987. Insect tolerant transgenic tomato plants. Biotechnology 5, 807-813.

Hofte, H., De Greve, H., Seurinck, J., Jansens, S., Mahillon, J., Ampe, C., Vandekerckhove, J., Vanderbruggen, H., Van Montagu, M., Zabeau, M., 1986. Structural and functional analysis of a cloned delta endotoxin of Bacillus thuringiensis Berliner 1715. European Journal of Biochemistry 2, 273-280.

James, C., 2003. Preview: Global Status of Commercialized Transgenic Crops: 2003. ISAAA Briefs. No. 30. ISAAA: Ithaca, NY.

Johansen, D.A., 1940. Plant Micro techniques. McGraw Hill Book Company, New York.

Kakani, V. G., Reddy, K.R., Zhao, D., Mohammed, A.R., 2003. Effects of ultraviolet radiation on cotton (Gossypium hirsutum L.) morphology and anatomy. Annals of Botany 91, 817-826.

Kranthi, K.R, Naidu, S., Dhawad, C.S., Tatwawadi, A., Mate, K., Patil, E., Bharose, A.A., Behere, G.T., Wadaskar, R.M., Kranthi, S., 2005. Temporal and intra-plant variability of Cry1Ac expression in Bt-cotton and its influence on the survival of the cotton bollworm, Helicoverpa armigera (Hubner) (Noctuidae: Lepidoptera). Current Science 89, 291-292.

Lu, Z., Chen, J., Percy, R.G., Zeiger, E., 1997. Photosynthetic rate, stomatal conductance and leaf area in two cotton species (Gossypium barbadense and Gossypium hirsutum) and their relation with heat resistance and yield. Australian Journal of Plant Physiology 24, 693-700.

O’brien, T.P., Feder, N., Mccull, M.E.,1964. Polychromatic staining of plant cell walls by toluidine blue $\mathrm{O}$. Protoplasma 59, 366-373.

Perlak, F.J., Deaton, R.W., Armstrong, T.A., Fuchs, R.L., Sims, S.R., Green Plate, T.J., Fischoff, D.A., 1990. Insect resistant cotton plants. Biotechnology 8, 939-943.

Radin, J.W., Lu, Z., Percy, R.G., Zeiger, E., 1994. Genetic variability for stomatal conductance in Pima cotton and its relation to improvements of heat adaptation. Proceedings of the National Academy of Sciences of the USA 91, 7217-7221.

Robert Van Den Bosch.,1980.The pesticide conspiracy. Prism Press, Stable Court, Chalmington, Dorchester, Dorset, DT2 OHB. 
Sass, J.E., 1940. Elements of botanical micro-technique. McGraw Hill Book Company, New York.

Scott, M.P., 2000. Development: The natural history of genes review. Cell 100, 27-40.

Sundaramurthy, V.T., 1994. Upsurgence of Whitefly Bemisia tabacci Gen. in the cotton ecosystem in India. Outlook on Agriculture 21, 79-83.

Sundaramurthy, V.T., 2002. The integrated insect management system and its effects on the environment and productivity of cotton. Outlook on Agriculture 31, 95-106.

Sundaramurthy, V.T., 2010. The impacts of the transgenes on the modified crops, non-target soil and terrestrial organisms. African Journal of Biotechnology 9, 91639176.

Wise, R.R., Gretchen, F., Sassenrath-Cole., Percy, R.G., 2000. A Comparison of leaf anatomy in field-grown Gossypium hirsutum and G. barbadense. Annals of Botany 86, 731-738. 